Article

\title{
Why Does the Halophyte Mesembryanthemum crystallinum Better Tolerate Ni Toxicity than Brassica juncea: Implication of Antioxidant Defense Systems
}

\author{
Taoufik Amari ${ }^{1}\left(\right.$, Aymen Souid ${ }^{1}{ }^{(D}$, Rim Ghabriche ${ }^{1}$, Mauro Porrini ${ }^{2}$, Stanley Lutts ${ }^{3}$, \\ Gian Attilio Sacchi ${ }^{2}$, Chedly Abdelly ${ }^{1}$ and Tahar Ghnaya ${ }^{1,4, *}$ \\ 1 Laboratoire des PlantesExtrêmophiles, Centre de Biotechnologie de Borj-Cédria, BP 901, \\ Hammam-lif 2050, Tunisia; taoufik.amari@gmail.com (T.A.); souid_aymen2008@yahoo.fr (A.S.); \\ Rimghabriche@gmail.com (R.G.); chedly.abdelly@gmail.com (C.A.) \\ 2 Department of Agricultural and Environmental Sciences, UniversitàdegliStudi di Milano, 20133 Milan, Italy; \\ Mauro.Porrini@unimi.it (M.P.); gianattilo.sacchi@unimi.it (G.A.S.) \\ 3 Groupe de Recherche enPhysiologieVégétale (GRPV), Earth and Life Institute, Université Catholique de \\ Louvain, 1348 Louvain-la-Neuve, Belgium; stanley.lutts@uclouvain.be \\ 4 Higher Institute of Arts and Crafts of Tataouine, University of Gabes Erriadh City, Zrig-Gabes 6072, Tunisia \\ * Correspondence: tahar.ghnaya@gmail.com; Tel.: +216-79-325-848; Fax: +216-98629-399
}

Received: 15 December 2019; Accepted: 19 February 2020; Published: 2 March 2020

\begin{abstract}
The implication of enzymatic and non-enzymatic antioxidative systems in response to $\mathrm{Ni}$ was evaluated in the halophyte Mesembryanthemum crystallinum in comparison with the metal tolerant glycophyte species Brassica juncea. Seedlings of both species were hydroponically subjected during 21 days to $0,25,50$, and $100 \mu \mathrm{M} \mathrm{NiCl}_{2}$. Growth parameters showed that the halophyte $M$. crystallinum was more tolerant to Ni than B. juncea. Malondialdehyde (MDA) content increased to a higher extent in B. juncea than in M. crystallinum. Antioxidant enzymesactivities were differently affected by Ni in both species. Nickel increased shoot superoxide dismutase (SOD) and ascorbate peroxidase (APX) activities in B. juncea, whereas these activities were reduced in $M$. crystallinum when exposed to metal stress. The root SOD, APX and guaiacol peroxidase (GPX) activities increased upon Ni treatments for both species. The content of non-enzymatic antioxidative molecules such as glutathione, non-protein thiols and proline increased in Ni-treated plants, except for GSH content in the shoot of $B$. juncea. Based on the oxidative balance, our findings confirm the higher tolerance of the halophyte $M$. crystallinum to Ni-induced oxidative stress comparatively to B. juncea. We suggest that $M$. crystallinum is able to overcome the produced ROS using the non-enzymatic system, while $\mathrm{Ni}$-induced oxidative stress was more acute in B. juncea, leading this species to mainly use the enzymatic system to protect against reactive oxygen species.
\end{abstract}

Keywords: antioxidant systems; glycophyte; halophyte; nickel stress; phytoremediation

\section{Introduction}

Anthropogenic activities including industrialization, urbanization and agricultural practices are the main factors responsible for an excessive accumulation of toxic metals in the environment. These non-biodegradable elements accumulate in the superficial soil horizons, groundwater and surface water. They may then be absorbed by plants and constitute a major risk for human contamination by the trophic chain [1-3]. These pollutants are indeed frequently reported as the primary causes of several human pathologies [4]. Their extraction from contaminated soils thus constitutes a priority for ecosystem stability and human health. In this context, several physicochemical methods have been proposed, but most of them are very expensive, require sophisticated equipment and specialized 
staff, and may destroy soil texture and telluric microorganisms. Nickel (Ni) is one of the most potentially harmful heavy metals for living organisms $[5,6]$. It has been released into the environment through various sources such as smelting, industrial wastes, burning of fossil fuel, mining and organic manures [6,7]. In plants, it is well documented that $\mathrm{Ni}$ is an essential micronutrient and plant cannot complete their life cycle without adequate levels of this metal ( 0.01 to $10 \mathrm{mg} \mathrm{g}^{-1} \mathrm{DW}$ ) [8]. Nickel is indeed required for normal activities of several enzymes (metalloenzymes), including urease involved in nitrogen metabolism of higher plants [9]. However, an excess of Ni becomes toxic for most plant species [10].

In plants, $\mathrm{Ni}$ is essentially absorbed through the root system via both passive diffusion and active transport [7] (Yusuf et al., 2011). However, the relative involvement of each pathway in total Ni uptake by plants varies between species as well as the chemical speciation and concentration of $\mathrm{Ni}$ in soil or nutrient solution $[7,11]$. The molecular basis of $\mathrm{Ni}$ absorption is still not well understood, although many transporters from the ZRT/IRT-like (ZIP) family are thought to be involved in this process [12]. De la Torre et al. [13] suggested that IRT1 is the essential route for Ni uptake in A. thaliana, since under Fe limiting conditions, the wild-type is able to accumulate 3 times more Ni than irt1 mutant. An increased $\mathrm{Ni}$ uptake was also reported in Arabidopsis tahliana under Zn-deficiency suggesting the implication of Zn-transporter ZIP3 in Ni absorption [11]. However, in the Ni-hyperaccumulators Alyssum inflatum and Alyssum bracteatum, $\mathrm{Ni}$ up take is not affected by $\mathrm{Zn}$ concentrations in the medium [14]. Some members of Nramp (natural resistance-associated macrophage protein) family were also reported to be directly involved in Ni transport in plants [15].

Excess $\mathrm{Ni}$ induces severe physiological/biochemical alterations and leads to symptoms of toxicity, such as chlorosis and foliar necrosis, ultimately culminating in a sharp decline in crop production [8]. Nickel may impair photosynthesis, water use efficiency, mineral uptake, and thus results in growth retardation [16-18]. Numerous studies reported thatNi phytotoxicity induces oxidative stress due to reactive oxygen species (ROS) overproduction [19] such as hydroxyl radicals $(\mathrm{OH} \cdot)$, superoxide anion $\left(\mathrm{O}_{2}{ }^{-}\right)$and hydrogen peroxide $\left(\mathrm{H}_{2} \mathrm{O}_{2}\right)[10,16,20]$. As a non-redox-active metal, $\mathrm{Ni}^{2+}$ cannot directly generate these oxidative molecules, but it may indirectly interfere with the antioxidant system responses. High levels of reactive oxygen species (ROS) in plant tissues can oxidize biological macromolecules, leading to major cellular damages, such as DNA alterations, oxidation of proteins and lipid peroxidation [21-23].

Some plant species are nevertheless able to cope with elevated Ni content in their shoots without expressing these toxicity symptoms. These so-called "hyperaccumulating plant species", Develop a wide range of defense mechanisms involving enzymatic and non-enzymatic antioxidant systems, which can alleviate cellular oxidative damages by scavenging ROS species.Gill and Tuteja [23]; Ghnaya et al. [24]; Mnasri et al. [25] and Amari et al. [26] demonstrated that, under heavy metals stress, some halophyte plant species (Sesuvium portula-castrum and Mesembryanthemum crystallinum) are able to fix metals to organic and amino acids. It was demonstrated that, in plants exposed to abiotic stresses, free proline exhibits a powerful antioxidant activity required to avoid ROS deleterious effects $[19,23,27]$. This amino acid could be also directly involved in metal ion chelation [28-30]. Glutathione (GSH) metabolism could also play an important role in maintaining the oxidative status in plants exposed to metal stress [31]. GSH is an essential tripeptide ( $\gamma$-glutamylcysteinyl glycine, $\gamma$-Glu-Cys-Gly) that plays a fundamental dual role: first, as an antioxidant to mitigate the redox imbalance caused by toxic metal accumulation and second, as a precursor of the ligand peptides phytochelatins responsible for free metal ion chelation and compartmentation in the vacuole [32]. Furthermore, several key antioxidants enzymes, such as catalase (CAT), guaïacol peroxidase (GPX), superoxide dismutase (SOD) and the enzymes of the ascorbate glutathione cycle including ascorbate peroxidase (APX) assume key functions in the ROS detoxifying process $[33,34]$ and it was shown that the activities of these major antioxidant enzymes can be significantly enhanced in plants subjected to Ni toxicity [35].

In numerous areas of the world, salt affected areas with low population often constitute sites for industrial and urban wastes contaminated with heavy metals [36,37]. Most of the Ni-hyperaccumulating 
plants are glycophytes species unable to tolerate salinity and consequently cannot be used to extract metals from salty contaminated soils. More recently, it has been demonstrated that halophytes, are able to cope with metal constraint more efficiently than glycophytes [24,38-40], suggesting their interest for phytoextraction of heavy metals on salt-affected substrates.

In an earlier study, we demonstrated that the halophyte Mesembryanthemum crystallinum accumulated much more $\mathrm{Ni}^{2+}$, than the glycophyte Brassica juncea (glycophyte) $[18,26]$. Interestingly, the halophyte species showed a better aptitude to maintain photosynthetic activity and pigment concentrations and to preserve the PSII functional integrity when challenged with Ni excess [18]. The ability of M. crystallinum to tolerate high Ni concentration could be related to the accumulation of organic acids and histidine in tissues, which are potential metal ligands that specifically bind nickel in the cytosol or in subcellular compartments [26]. The role of the antioxidant defense system in $\mathrm{Ni}^{2+}$-tolerance of $M$. crystallinum remains poorly studied and the involvement of enzymes and non-enzymatic compounds in plants exposed to toxic doses of $\mathrm{Ni}^{2+}$ still needs to be clarify. Therefore, the aim of the present study was to perform a comparative evaluation of the antioxidant defense in M. crystallinum (halophyte) and B. juncea (glycophyte) when subjected to nickel stress, through physiological parameters related to lipid peroxidation and enzymatic/non-enzymatic antioxidant system.

\section{Materials and Methods}

\subsection{Plant Material and Culture Conditions}

The seeds of Mesembryanthemum crystallinum were collected from their natural habitat near Thina (Sfax, $300 \mathrm{~km}$ South of Tunis) while those of Brassica juncea (Acc PI 173874) were kindly provided by the North Central Regional Plant Introduction Station (NCRPIS-USDA-USA). Seeds of both species were sterilized using $10 \% \mathrm{H}_{2} \mathrm{O}_{2}$ solution during $20 \mathrm{~min}$, then washed with distilled water and sown on perlite imbibed with distilled water placed for 4 days in the dark at $24 \pm 1{ }^{\circ} \mathrm{C}$ room temperature and $70 \%$ relative humidity. Two weeks after germination, plants were grown hydroponically for 3 weeks in pots filled with $5 \mathrm{~L}$ continuously aerated Hoagland's nutrient solution (8 plants per pot) [41]. The experiment was carried out under growth chamber conditions with $25 \pm 1 / 18 \pm 1^{\circ} \mathrm{C}$ temperature, $55 / 75 \%$ relative humidity $(\mathrm{RH})$ and $16 \mathrm{~h} / 8 \mathrm{~h}$ photoperiod day/night regime. Solutions were renewed every 3 days to avoid depletion of nutrients and $\mathrm{Ni}$ concentrations. $\mathrm{pH}$ was adjusted to 5.8. An initial harvest was performed just before $\mathrm{Ni}$ application to characterize the initial plant size and weight. $\mathrm{Ni}$ treatments were applied to obtain a final concentration of $0,25,50$ and $100 \mu \mathrm{M} \mathrm{NiCl}_{2}$ (Sigma-Aldrich) ( 3 pots per treatment). After 3 weeks, Ni-treated and control plants were harvested and used for physiological and biochemical analyses.

\subsection{Growth Analysis}

At the harvest, plants (6 replicates per treatment) were divided into shoots and roots. Shoots were rinsed three times with cold distilled water and blotted between two layers of filter paper. Roots were immediately dipped in a cold solution of $\mathrm{HCl}(0.01 \mathrm{M})$ for $5 \mathrm{~min}$ to dissolve metals adsorbed on the root surface [42] and then washed three times with cold distilled water and blotted with filter paper. The fresh weight was immediately determined, and the dry weight was measured after $48 \mathrm{~h}$ of desiccation in an oven at $60^{\circ} \mathrm{C}$.

The relative growth rate (RGR) was calculated according to Hunt (1990) [43]:

$$
\mathrm{RGR}=\ln \mathrm{M}_{2}-\operatorname{LnM}_{1} /\left(\mathrm{t}_{2}-\mathrm{t}_{1}\right)
$$

where $\mathrm{M}_{2}$ and $\mathrm{M}_{1}$ were the dry matter at the final and initial harvests, respectively, and $\left(t_{2}-t_{1}\right)$ was the nickel treatment duration (days). 


\subsection{Estimation of Lipid Peroxidation}

The extent of lipid peroxidation was estimated by determining the amount of malondialdehyde (MDA) in plant tissues by the method of Hodges et al. [44], which takes into account the possible influence of interfering compounds in the thiobarbituric acid (TBA)-reactive substances assay. MDA contents were measured on the roots and leaves of B. juncea and M. crystallinum exposed to all treatments. Fresh samples were extracted for $45 \mathrm{~min}$ with 80:20 (v/v) ethanol/water using an ultrasonic cleaner (Bransonic, Danbury, CT). The homogenate was centrifuged at $15,000 \times g$ for $10 \mathrm{~min}$. Then the pellet was reextracted twice with the same solvent. Supernatants were pooled and an aliquot was added to a test tube with an equal volume of either (1) - TBA solution containing $20 \%(w / v)$ trichloroacetic acid and $0.01 \%(w / v)$ BHT, or (2) + TBA solution containing the above added with $0.65 \%$ $(w / v)$ TBA. Samples were heated at $95^{\circ} \mathrm{C}$ for $25 \mathrm{~min}$ and after cooling, absorbance was read at 440, 532 and $600 \mathrm{~nm}$. MDA equivalents were calculated as $106 \times[(\mathrm{A}-\mathrm{B}) / 157,000]$, where $\mathrm{A}=(\mathrm{Abs} 532+\mathrm{TBA})$ $-($ Abs $600+$ TBA $)-[($ Abs 532-TBA $)-($ Abs $600-$ TBA $)]$, and B $=($ Abs $440+$ TBA $)-[($ Abs $600+$ TBA) $\times 0.0571]$.

\subsection{Enzyme Extractions}

All of the following operations were performed at $4{ }^{\circ} \mathrm{C}$. The fresh leaves and roots samples $(0.5 \mathrm{~g})$ were rapidly extracted in a prechilled mortar with 10\% (w/w) PVP (polyvinylpyrrolidone) in $50 \mathrm{mM}$ K-phosphate buffer ( $\mathrm{pH}$ 8), containing $0.1 \mathrm{mM}$ EDTA (ethylenediaminetetraacetic acid), $1 \mathrm{mM}$ DTT (dithiothreitol), and 0.5 mM PMSF (phenyl-methyl-sulphonyl-fluoride). For APX activity, $20 \mathrm{mM}$ ascorbate was added to the extraction medium to maintain the enzyme active during extraction. The homogenates were centrifuged at $12.000 \times g$ for $30 \mathrm{~min}$. For APX, the supernatant was dialyzed for $2 \mathrm{~h}$ against the same buffer used for the homogenization containing $5 \mathrm{mM}$ sodium ascorbate. Three replicates per treatment were used. The supernatants were collected and their protein concentrations were determined according to Bradford [45], using bovine serum albumin as a standard.

\subsection{Enzyme Assays}

The total activity of the SOD (EC 1.11.1.5) in the roots and shoots was measured according to Scebba et al. [46]. Different volumes of organ crude extracts $(5,10,20$, and $40 \mu \mathrm{L})$ were added to the reaction mixture reaching a final volume of $3 \mathrm{~mL}$. The reaction mixture contains $50 \mathrm{mM}$ potassium phosphate buffer ( $\mathrm{pH}$ 7.8), $0.1 \mathrm{mM}$ EDTA, $13 \mathrm{mM}$ L-methionine, $2 \mu \mathrm{M}$ riboflavin and $75 \mu \mathrm{M}$ NBT (nitroblue tetrazolium). The reaction was started by exposing the mixture to cool white fluorescent light for $15 \mathrm{~min}$. The blue reaction color was measured spectrophotometrically at $560 \mathrm{~nm}$. The control reaction mixture had no enzyme extract, while blanks had the same complete reaction mixture, but were kept in the dark. The volume of sample that induces 50\% inhibition of color development was considered as one unit of SOD activity and the activity was expressed as units per mg of protein.

The total activity of CAT (EC 1.11.1.6) was assayed spectrophotometrically referring to the method of Luck [47] by monitoring the decline in absorbance at $240 \mathrm{~nm}$ as $\mathrm{H}_{2} \mathrm{O}_{2}$ was consumed, against a plant extract-free blank. The $3 \mathrm{~mL}$ reaction mixture contained $66 \mathrm{mM}$ sodium phosphate buffer ( $\mathrm{pH} 7.0$ ), to which $30 \%(w / v) \mathrm{H}_{2} \mathrm{O}_{2}$ was added (the optical density was around 0.5 at $240 \mathrm{~nm}$ with a $1 \mathrm{~cm}$ light path). The reaction was initiated by adding an appropriate dilution of the shoot or root crude extract to this solution. The time required for a decrease in the optical density of from 0.45 to 0.4 was used for CAT activity calculations. CAT activity was expressed as unit per mg of protein. A unit is the amount of an enzyme which liberates half the peroxide oxygen from a hydrogen peroxide solution of any concentration in $100 \mathrm{~s}$ at $25^{\circ} \mathrm{C}$.

The total APX (EC 1.11.1.11) activity was measured according to Nakano and Asada [48] by following the decline in absorbance at $290 \mathrm{~nm}$ as ascorbate was oxidized $\left(\mathrm{R}=2.8 \mathrm{mM}^{-1} \mathrm{~cm}^{-1}\right)$. The rate of ascorbate oxidation was estimated between 1st and 60th $\mathrm{s}$ after starting the reaction with the addition of $\mathrm{H}_{2} \mathrm{O}_{2}$. The $1 \mathrm{~mL}$ reaction mixture contained $50 \mathrm{mM}$ HEPES-NaOH (pH 7.6), 0.22 mM 
ascorbate, $1 \mathrm{mM} \mathrm{H}_{2} \mathrm{O}_{2}$ and an enzyme sample. The control reaction mixture was prepared without adding the enzyme extract. Corrections were made for the low, non-enzymatic oxidation of ascorbate by $\mathrm{H}_{2} \mathrm{O}_{2}$ and for the oxidation of ascorbate in the absence of $\mathrm{H}_{2} \mathrm{O}_{2}$. The activity was expressed as units ( $\mu \mathrm{mol}$ of oxidized ascorbate per $\mathrm{min}$ ) per $\mathrm{mg}$ of protein.

The total GPX activity was determined according to Fielding and Hall [49] by following the increase in absorbance at $470 \mathrm{~nm}$ when adding the enzymatic preparation to $2 \mathrm{~mL}$ of guaiacol $(0.5 \%)$ and $9 \mathrm{mM}$ hydrogen peroxide $\left(\mathrm{H}_{2} \mathrm{O}_{2}\right)$ in $\mathrm{K}$-phosphate buffer (50 mM, pH 7.0).

\subsection{Non-Protein Thiols Determination}

NPT concentration was determined according to Rijstenbil et al. [50]. Briefly, $100 \mathrm{mg}$ of freeze-dried tissue of roots and leaves were crushed and homogenized in ice. The powder was suspended in $1 \mathrm{~mL}$ of a mixture of $236 \mathrm{mM}$ sulfosalicylic acid SSA, $6.3 \mathrm{mM}$ diethylenetriamine pentaacetic acid (DTPA) at $\mathrm{pH}$ 2. This solution was used to keep the thiols in reduced state. Homogenates were sonicated. Cell residues were removed by centrifugation at $12,000 \times g$ for $20 \mathrm{~min}$ at $8{ }^{\circ} \mathrm{C}$. The $\mathrm{SH}$ group of non-protein thiol forms a DTNB (dithionitrobenzoic acid)-SH complex that was spectrophotometrically measured at $412 \mathrm{~nm}$. In each case, at least 5 samples were analyzed.

\subsection{Glutathione Determination}

The aliquots of the fresh leaf and root tissue $(0.5 \mathrm{~g})$ were crushed and homogenized in ice-cold $5 \%(w / v)$ TCA, using a cold mortar and pestle, then centrifuged at $15,000 \times g$ for $10 \mathrm{~min}$ at $4{ }^{\circ} \mathrm{C}$. Total (GSH + GSSG) and oxidized glutathione (GSSG) were determined in the supernatant by the 5,5-dithiobis-nitrobenzoic acid (DTNB)-GR recycling procedure as reported in Sgherri and Navari-Izzo [51]. Changes in the absorbance of the reaction mixture were measured at $412 \mathrm{~nm}$ at $25{ }^{\circ} \mathrm{C}$. The total glutathione concentration was calculated from a standard curve in which GSH equivalents (1-10 nmol) were plotted against the rate of change at $412 \mathrm{~nm}$.

\subsection{Free Proline Concentration}

For proline determination, the frozen root and leaves samples were homogenized in $3 \mathrm{~mL}$ of $1 \mathrm{mM}$ tridecafluoroheptanoic acid (TDFHA), 50\% (v/v) methanol. Samples were shaken for $10 \mathrm{~min}$ at $4{ }^{\circ} \mathrm{C}$ and then centrifuged twice at $14,000 \times g$ for $20 \mathrm{~min}$ at $4{ }^{\circ} \mathrm{C}$. The underivatized supernatant was finally diluted to $0.5 \mathrm{mM}$ TDFHA, 25\% (v/v) methanol. The LC-ESI-MS analysis was conducted using an Agilent Technologies 1200 Series capillary pump coupled with dual ESI source on a 6520 Q-TOF mass spectrometer according to Armstrong et al. [52]. Briefly, LC runs were done on an XDB-C18 column $(2.1 \times 50 \mathrm{~mm}, 1.8 \mu \mathrm{m}$, Agilent Technologies) applying a 30 min non-linear gradient of $0.5 \mathrm{mM}$ TDFHA/acetonitrile with a flow rate of $200 \mu \mathrm{L} / \mathrm{min}$. The ESI source was set at $350{ }^{\circ} \mathrm{C}, 3500 \mathrm{~V}$, and fragmentor at $100 \mathrm{~V}$. The data acquisition range was $50-350 \mathrm{~m} / \mathrm{z}$ at $0.93 \mathrm{scans} / \mathrm{s}$. The quantization was conducted on EIC for single $\mathrm{MH}^{+}$in a $\pm 0.02 \mathrm{~m} / \mathrm{z}$ window, accepting a mass error of $\pm 5 \mathrm{mDa}$ in ion identification and referring to calibration curves in the adequate concentration range.

\subsection{Statistical Analysis}

ANOVA with orthogonal contrasts and mean comparison procedures were used to detect differences between treatments. Mean separation procedures were conducted using Duncan's multiple range tests with least significant difference (LSD) $(p<0.05)$.

\section{Results}

\subsection{Plant Morphology and Growth}

After eight days of $\mathrm{Ni}$ treatment, chlorosis was visible in young leaves of B. juncea exposed to $\mathrm{Ni}^{2+}$. One week later, chlorosis intensity increased and necrosis appeared in oldest leaves, with a subsequent falling of these senescing leaves at the highest $\mathrm{Ni}^{2+}$ concentrations (50 and $\left.100 \mu \mathrm{M}\right)$. In 
contrast, such toxicity symptoms were not observed on leaves of Ni-treated M. crystallinum plants, even at the highest Ni concentration $(100 \mu \mathrm{M})$. Both root (RDW) and shoot biomasses (SDW) decreased significantly in the two considered species with increasing $\mathrm{Ni}^{2+}$ concentrations (Table 1).

Table 1. Of different $\mathrm{NiCl}_{2}$ external concentrations on root biomass (RDW), shoot biomass (SDW), the whole plant dry weight (WPDW) and relative growth rate (RGR) of M. crystallinum and B.juncea after 21 days of treatment. According to ANOVA, LSD 0.05 test and considering each species alone and for the same column, means $(n=6$ per treatment $\pm \mathrm{SE}$ ) with at least one same letter are not significantly different.

\begin{tabular}{ccccc}
\hline $\mathbf{N i C l}_{\mathbf{2}}$ & RDW $\mathbf{( g )}$ & SDW $(\mathbf{g})$ & WPDW $(\mathbf{g})$ & ${\text { RGR }\left(\mathbf{d}^{-1}\right)}$ \\
\hline M. crystallinum & & & & \\
0 & $0.70 \pm 0.06 \mathrm{a}$ & $2.17 \pm 0.11 \mathrm{a}$ & $2.77 \pm 0.12 \mathrm{a}$ & $0.081 \pm 0.003 \mathrm{a}$ \\
25 & $0.47 \pm 0.02 \mathrm{~b}$ & $1.62 \pm 0.04 \mathrm{~b}$ & $2.09 \pm 0.03 \mathrm{~b}$ & $0.075 \pm 0.004 \mathrm{~b}$ \\
50 & $0.41 \pm 0.03 \mathrm{c}$ & $1.41 \pm 0.07 \mathrm{c}$ & $1.82 \pm 0.10 \mathrm{c}$ & $0.064 \pm 0.004 \mathrm{c}$ \\
100 & $0.30 \pm 0.02 \mathrm{~d}$ & $0.89 \pm 0.04 \mathrm{~d}$ & $1.19 \pm 0.08 \mathrm{~d}$ & $0.049 \pm 0.002 \mathrm{~d}$ \\
B. juncea & & & \\
0 & $1.19 \pm 0.10 \mathrm{a}$ & $5.22 \pm 0.32 \mathrm{a}$ & $6.41 \pm 0.41 \mathrm{a}$ & $0.121 \pm 0.004 \mathrm{a}$ \\
25 & $0.89 \pm 0.09 \mathrm{~b}$ & $3.94 \pm 0.28 \mathrm{~b}$ & $4.82 \pm 0.37 \mathrm{~b}$ & $0.086 \pm 0.004 \mathrm{~b}$ \\
50 & $0.61 \pm 0.04 \mathrm{c}$ & $2.13 \pm 0.14 \mathrm{c}$ & $2.76 \pm 0.18 \mathrm{c}$ & $0.054 \pm 0.002 \mathrm{c}$ \\
100 & $0.50 \pm 0.05 \mathrm{~d}$ & $1.60 \pm 0.21 \mathrm{~d}$ & $2.1 \pm 0.26 \mathrm{~d}$ & $0.042 \pm 0.003 \mathrm{~d}$ \\
\hline
\end{tabular}

On average, the reduction percentage observed for the whole plant biomasses production at $50 \mu \mathrm{M}$ as compared to control reached $35 \%$ and $58 \%$ in $M$. crystallinum and B. juncea, respectively (Table 1). Based on this parameter, the halophyte $M$. crystallinum maintained a better growth in the presence of $\mathrm{Ni}$ as compared to B. juncea.

Mesembryanthemum crystallinum was characterized by a lower RGR as compared to B. juncea (0.081 and $0.12 \mathrm{~d}^{-1}$ respectively) on Ni-free solution. The detrimental effect of $\mathrm{Ni}^{2+}$ exposure on the plant growth activity was more pronounced in B. juncea than M.crystallinum as reflected by the sharper decrease of RGR in the former species (-55\% as compared to the control values at $50 \mu \mathrm{M} \mathrm{NiCl}_{2}$ versus $-21 \%$ in $M$. crystallinum).

\subsection{Ni Effect on Malondialdehyde (MDA) and Proline Tissus Contents}

The determination of the oxidation of polyunsaturated fatty acids estimated by the production of the MDA showed increased values in leaves of Ni-treated B. juncea (Figure 1) as compared to their respective controls. For instance, compared to the control, the MDA content increased by $260 \%$ at $100 \mu \mathrm{M} \mathrm{NiCl}_{2}$ in $\mathrm{B}$. juncea whereas it was only slightly affected in $\mathrm{M}$. crystallinum leaves whatever the Ni dose (Figure 1a). The lipid peroxidation was significantly increased in the roots of both B. juncea and M. crystallinum plants (Figure 1a). 


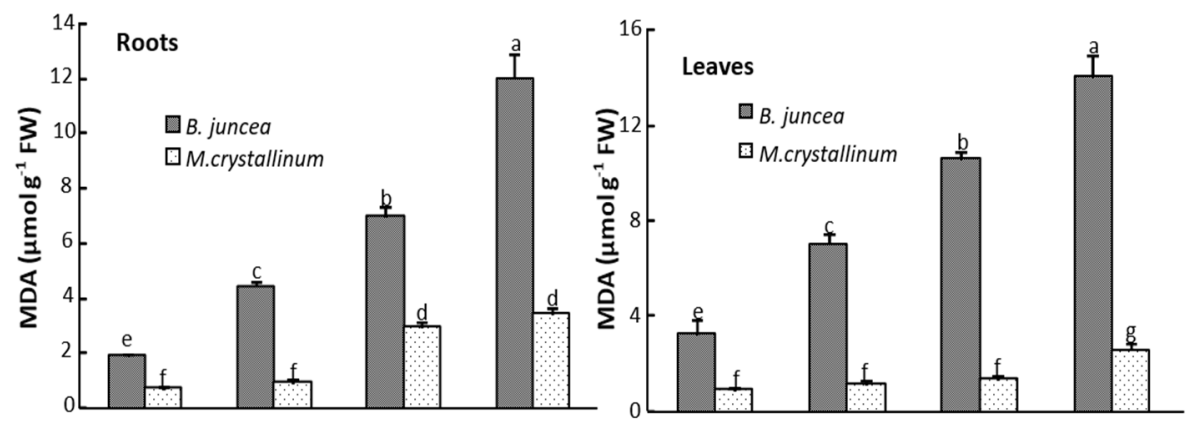

(a)
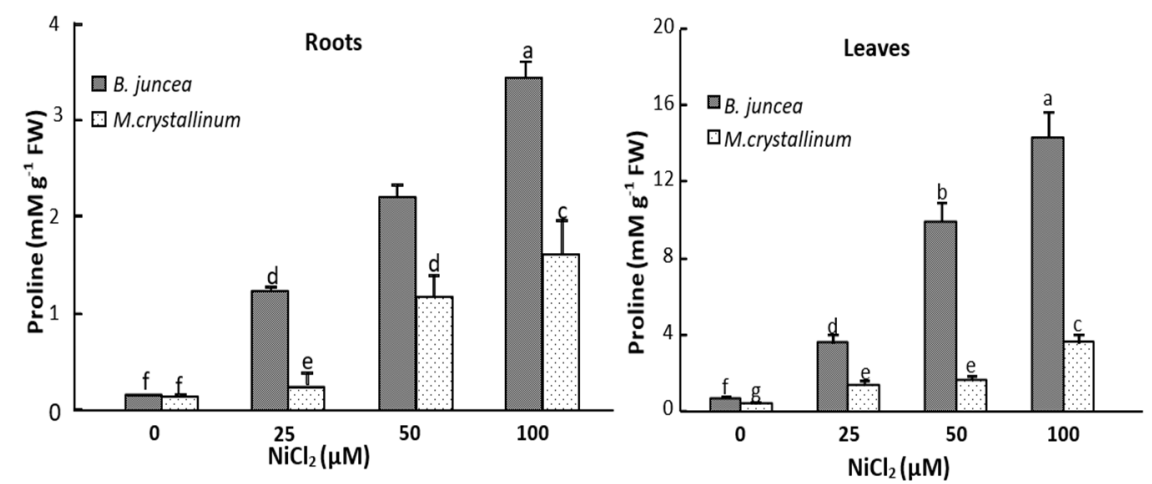

(b)

Figure 1. MDA (a) and proline (b) concentrations in the roots and leaves of M. crystallinum and B. juncea subjected during $21 \mathrm{~d}$ to different Ni concentrations. According to ANOVA, LSD 0.05 test, means $(n=6$ per treatment \pm SE) marked with the same letters are not significantly different.

$\mathrm{Ni}^{2+}$ led to a marked increase of proline concentration in B.juncea leaves, reaching $600 \%$ for all $\mathrm{Ni}$ treatments as compared to control. In M. crystallinum, we also noticed a significant increase in proline concentration with increasing $\mathrm{NiCl}_{2}$ concentrations in the medium (Figure $1 \mathrm{~b}$ ). A similar trend was observed in the roots of both species, with a lower extent as compared to leaves (Figure 1b) and it was especially marked at the highest $\mathrm{Ni}$ concentration $\left(100 \mu \mathrm{M} \mathrm{NiCl}_{2}\right)$.

\subsection{Leaf and Root Antioxidant Enzyme Activities}

In the leaves of B. juncea, SOD and APX activities significantly increased under all Ni-treatments (Figures 2 and 3), whereas the GPX activities decreased in Ni treated plants as compared to control (Figure 4). In contrast, SOD, APX and GPX activities significantly decreased under Ni treatments in the shoot of M. crystallinum shoots (Figures 2-4). In the roots of both species, Ni stimulated the activities of SOD and GPX (Figures 2 and 4), but the APX activity decreased in B. juncea roots under Ni treatment. The activity of all enzymes was higher in roots compared to leaves for both species when exposed to $\mathrm{Ni}^{2+}$. It is also worth mentioning that CAT show low activity in both species and was not affected by the Ni treatments. 

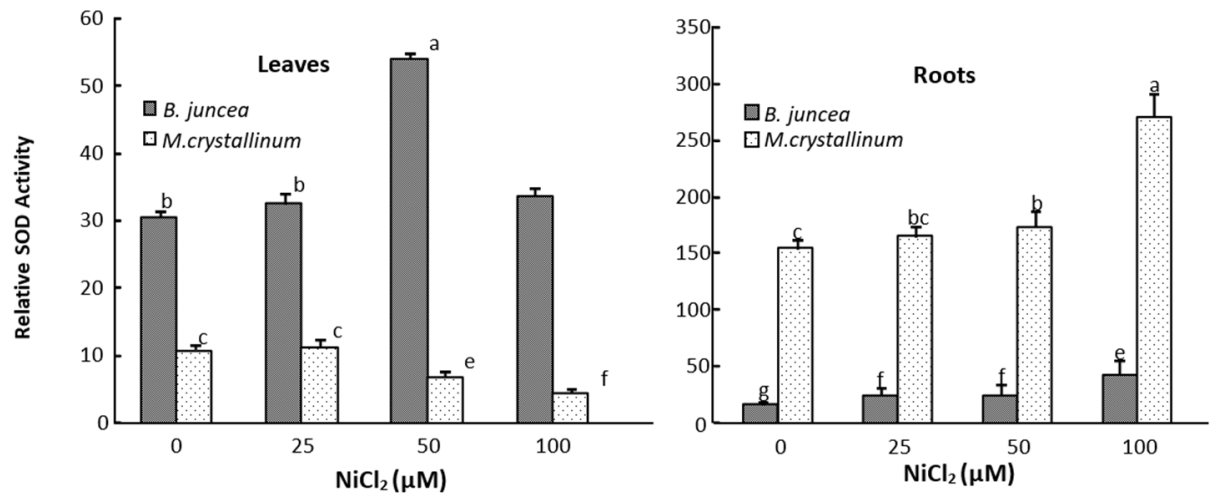

Figure 2. Superoxide dismutase (SOD) activity in the roots and leaves of M. crystallinum and B. juncea treated with different doses of $\mathrm{NiCl}_{2}$ during 21 days. According to ANOVA, LSD 0.05 test, means $(n=6$ per treatment $\pm \mathrm{SE}$ ) marked with the same letters are not significantly different.
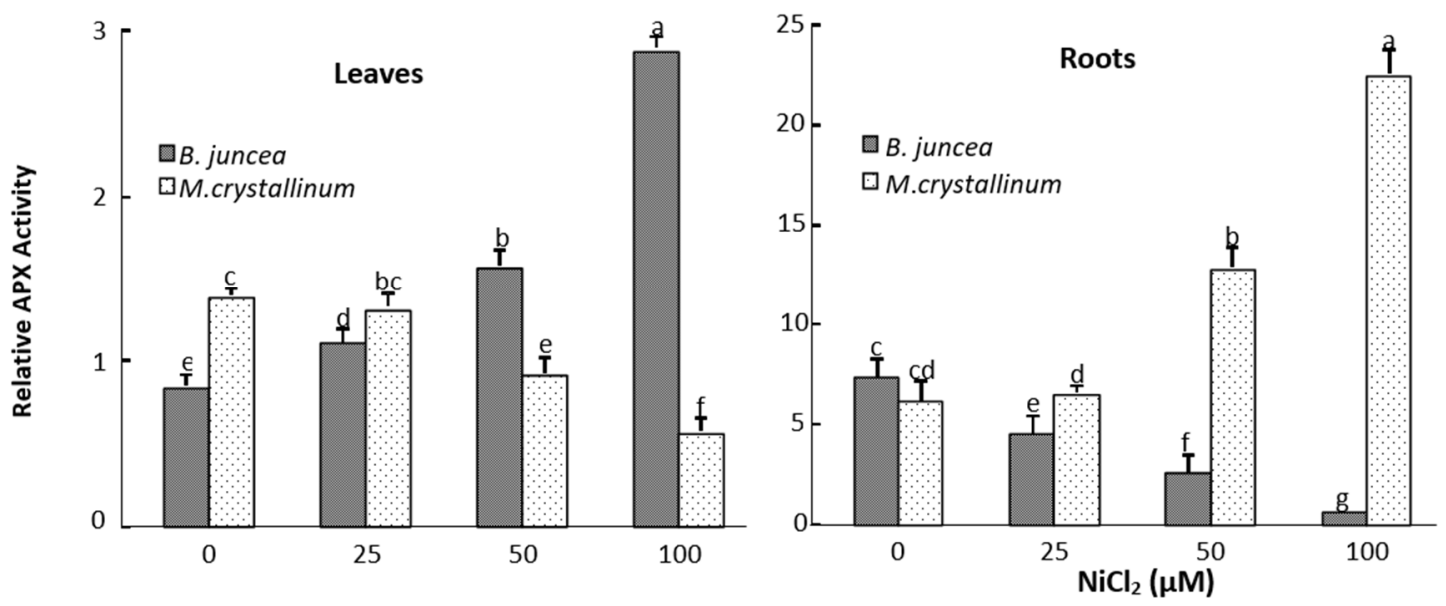

Figure 3. Ascorbate peroxidase (APX) activity in the roots and leaves treated of $\mathrm{NiCl}_{2}$-treated $M$. crystallinum and B. juncea. According to ANOVA, LSD 0.05 test, means ( $n=6$ per treatment \pm SE) marked with the same letters are not significantly different.
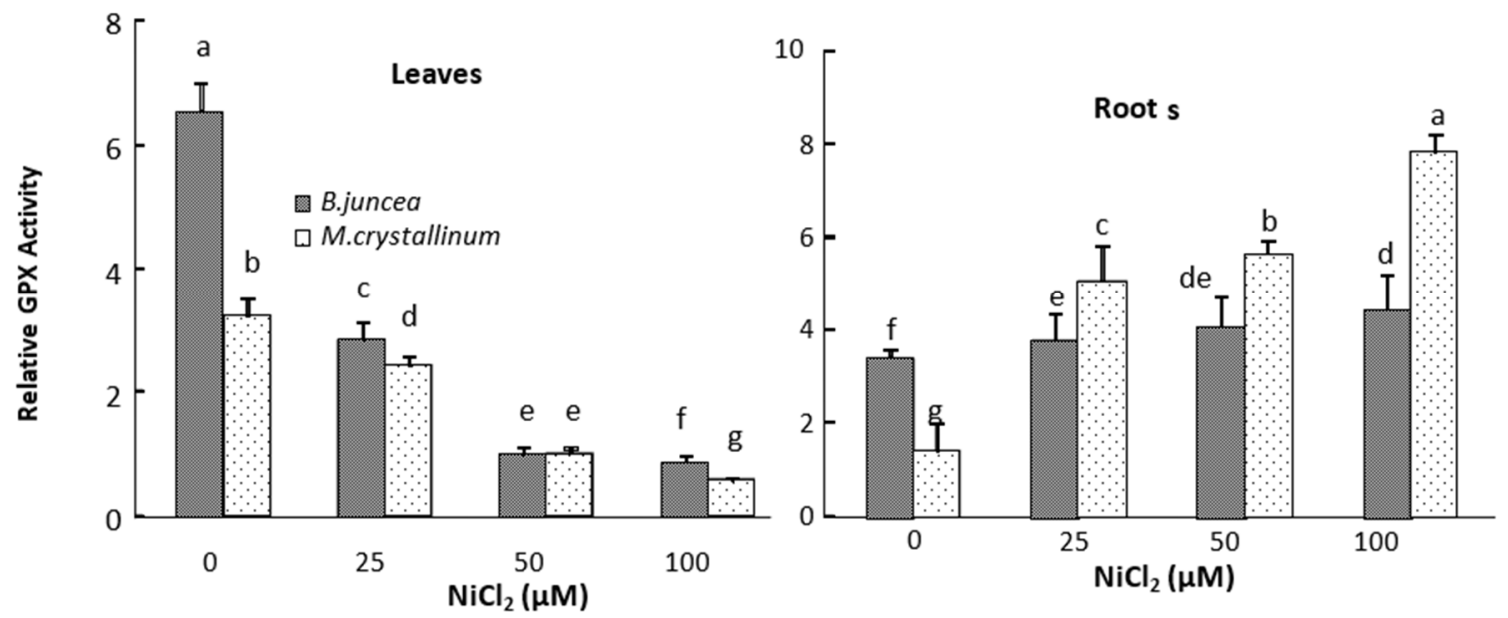

Figure 4. Guaiacol peroxidise (GPX) activity in the roots and leaves of M. crystallinum and B. juncea treated with $\mathrm{NiCl}_{2}$ during 21 days. According to ANOVA, LSD 0.05 test, means $(n=6$ per treatment \pm $\mathrm{SE})$ marked with the same letters are not significantly different. 


\subsection{Non-Protein Thiol and Glutathione Contents}

Non-protein thiol (NPT) and glutathione levels variations in the root and the shoot of both species subjected to Ni are displayed in Table 2. For both species, an increase in the Ni external concentration induced an increase in the root NPT concentrations which was significant for doses higher than $25 \mu \mathrm{M}$. As far as the shoots were concerned, we demonstrated that $25 \mu \mathrm{M} \mathrm{Ni}$ did not induce a significant modification of the concentration of NPT whereas a significant increase in NPT was recorded in both species at $100 \mu \mathrm{M} \mathrm{Ni}$, although it was more marked in M. crystallinum than in B. juncea. At the intermediate dose $(50 \mu \mathrm{M})$ an increase of NPT content was recorded in the shoots of M. crystallinum shoots while a significant decrease in this parameter was detected in B. juncea.

Table 2. The effect of different $\mathrm{NiCl}_{2}$ external concentrations on non-thiol protein (NPT) and glutathione (GSH) content of M. crystallinum and B. juncea. According to ANOVA, LSD 0.05 test and considering each species alone and for the same parameter at the same column, means $(n=6$ per treatment $\pm \mathrm{SE})$ with at least one same letter are not significantly different.

\begin{tabular}{|c|c|c|c|c|}
\hline \multirow[t]{2}{*}{$\mathrm{NiCl}_{2}(\mu \mathrm{M})$} & \multicolumn{2}{|c|}{ Brassica juncea } & \multicolumn{2}{|c|}{ Mesembryanthemum crystallinum } \\
\hline & Root & Shoot & Root & Shoot \\
\hline \multicolumn{5}{|c|}{ NPT (nmol/g FW) } \\
\hline $0 \mu \mathrm{M}$ & $305.29 \pm 29.13 c$ & $19.7 \pm 0.053 b$ & $301.90 \pm 26.18 b$ & $96.29 \pm 7.35 c$ \\
\hline $25 \mu \mathrm{M}$ & $301.47 \pm 28.12 c$ & $18.76 \pm 1.34 b$ & $309.90 \pm 6.13 b$ & $97.99 \pm 6.72 c$ \\
\hline $50 \mu \mathrm{M}$ & $457.81 \pm 40.74 \mathrm{ab}$ & $14.32 \pm 1.12 c$ & $547.60 \pm 24.52 \mathrm{a}$ & $156.45 \pm 12.61 b$ \\
\hline $100 \mu \mathrm{M}$ & $579.82 \pm 53.67 \mathrm{a}$ & $\begin{array}{l}82.74 \pm 5.21 \mathrm{a} \\
\mathrm{GSH}(\mu \mathrm{mol} / \mathrm{g} \mathrm{FW})\end{array}$ & $522.28 \pm 31.19 a$ & $601.30 \pm 55.11 a$ \\
\hline $0 \mu \mathrm{M}$ & $0.135 \pm 0.017 \mathrm{~d}$ & $0.147 \pm 0.006 a$ & $0.106 \pm 0.004 d$ & $0.221 \pm 0.005 b$ \\
\hline $25 \mu \mathrm{M}$ & $0.123 \pm 0.013 \mathrm{~cd}$ & $0.076 \pm 0.008 b$ & $0.136 \pm 0.001 c$ & $0.213 \pm 0.041 c$ \\
\hline $50 \mu \mathrm{M}$ & $0.205 \pm 0.012 b$ & $0.064 \pm 0.005 c$ & $0.172 \pm 0.015 b$ & $0.318 \pm 0.034 \mathrm{a}$ \\
\hline $100 \mu \mathrm{M}$ & $0.265 \pm 0.010 a$ & $0.068 \pm 0.004 c$ & $0.318 \pm 0.018 \mathrm{a}$ & $0.307 \pm 0.030 \mathrm{a}$ \\
\hline
\end{tabular}

Nickel induced a significant increase in root GSH concentration in B. juncea but decreased it in the shoot. In M. crystallinum, the increasing Ni external concentration induced a significant proportional increase in GSH contents in both shoots and roots.

\section{Discussion}

Nickel is an indispensable micronutrient for plants growth and it is required at lower concentrations in agricultural soils $[8,53]$. However, an excess of this element induces toxicity and drastically reduces plant growth and productivity $[7,22]$. Interestingly, at the physiological and metabolomic levels, plants respond differently to the stress induced by the excess of $\mathrm{Ni}[26,54]$. As we show in the present study, nickel adversely affected the plant growth in both species (Table 1). Based on plant growth parameters (DW and RGR), the halophyte M. crystallinum is more tolerant to Ni constraint than B. juncea. This tolerance was also evident when comparing plant morphology since $\mathrm{Ni}$ induced acute chlorosis and necrosis only in B.juncea plants.

Nickel is able to interfere with several other elements in several biological and chemical reactions. To date, several lines of evidence indicate that Ni toxicity in plants is associated with oxidative stress induction $[10,19,55,56]$ as reflected by the generation of hydroxyl radicals, superoxide anions, nitric oxide and hydrogen peroxide $[19,20]$. The high production of reactive oxygen species (ROS) during stress disturbs the cellular redox homeostasis, by enhancing oxidative processes such as protein oxidation, enzyme activity inhibition, membrane lipid peroxidation, and DNA and RNA damage [57]. Malondialdehyde (MDA), one of the decomposition products of polyunsaturated fatty acids of membrane, is regarded as a reliable indicator of oxidative stress [58]. In our conditions, the MDA concentrations increased in both roots and leaves of Ni-treated B.juncea plants, indicating that an oxidative stress appeared quickly following Ni-exposure. By contrast, the low content of MDA in Ni-treated M. crystallinum plants compared to B.juncea, indicates the high aptitude of this halophyte to 
preserve its membrane integrity against the peroxidation induced by Ni. These data confirm that the growth of the halophyte was less affected by $\mathrm{Ni}$.

Several previous data demonstrated that $\mathrm{Ni}$ induced MDA accumulation in many plant species. Boominathan and Doran, [55], Gajewska and Sklodowska [22,59] and Dubey and Pandey [60] reported an increase in MDA concentration in Alyssum bertolonii, Triticum aestivum and Vigna mungo plants when subjected to $\mathrm{Ni}$, respectively. This is notably due to the destruction of cell membranes flowing attack induced by the ROS generated by Ni. In fact, chloroplasts have a complex system of membranes rich in polyunsaturated fatty acids, which are potential targets of ROS for peroxidation [61].

The oxidative degradation of lipid of chloroplast membrane under heavy metal stress provokes alterations of the thylakoids structure, thus leading to the disruption of the plant photosynthetic activity [62]. Moreover, the changes in the lipid composition and the degree of unsaturated fatty acids induced by metals can directly cause biomembrane deterioration, especially affecting the fluidity and selective permeability of the membrane [63]. Hence, in our previous investigations, we showed a significant drop in B. juncea nutrients acquisition and photosynthesis under Ni constraint [18]. By contrast, Ni-treated M.crystallinum plants showed a better aptitude to maintain photosynthetic activity and pigment concentrations and to preserve the PSII functional integrity when challenged with $\mathrm{Ni}$ excess [18].

Several mechanisms could govern metal resistance in plants. Among them, the enzymatic antioxidant system is an important defense strategy co-evolved with aerobic metabolism as a response to metal-induced toxicity to counteract the ROS oxidative consequences. Indeed, antioxidant enzymes such as, superoxide dismutase (SOD), guaiacol peroxidase (GPX), ascorbate peroxidase (APX) and catalase (CAT) are notably implicated in the ROS-scavenging and contribute to regulation of cellular redox balance [33]. For example, SOD is usually considered as the first line of defense against oxidative stress [64]. By controlling the steady-state superoxide levels, SOD plays an essential protective role against cellular oxidative damage, because the superoxide ion acts as a precursor of more cytotoxic or highly reactive oxygen derivatives, such as peroxynitrite or hydroxyl radical [60]. In our experiment, nickel stress enhanced the SOD activity in the leaves of Ni-treated B.juncea plant, whereas it induced the decrease in this activity of this enzyme in M. crystallinum leaves. An increase in the SOD activity was also observed in the roots of both Ni-treated species.

In previous work, researchers demonstrated that the impact of metal constraint on the activity of antioxidant enzymes depend on the plant species, organs sampled, metal dose, and duration of exposure. For example, exposure of Coffea arabica [65] and Oryza sativa [35] to Ni provoked a significant increase in the SOD activity. Kumar et al. [66] also reported an enhanced activity of SOD in the roots and the leaves of Ni-treated Hordeum vulgare plants. However, Ni-treatment of Alyssum bestolonii, Nicotiana tabacum [55] and Hydrocharisdubia [67] resulted in a severe depletion of SOD activity.

One of the likely mechanisms which can explain the decreasing enzyme activity is related to the interaction of $\mathrm{Ni}^{2+}$ with ligand groups e.g., $-\mathrm{SH}$ of enzymes, inhibiting enzyme activity by hiding the prosthetic groups or protein denaturation [68]. $\mathrm{Ni}^{2+}$ may indirectly affect proteins, particularly metalloenzymes, by disturbance in the absorption of essential minerals such as $\mathrm{Fe}, \mathrm{Cu}, \mathrm{Zn}$ or $\mathrm{Mn}$ [69]. It can also competitively substitute the essential elements thus affecting the enzymes activity [17].

Our results showed that exposure of B. juncea and M. crystallinum plants to Ni resulted in reductions in GPX activity at the leaf level. Ni treatment also led to a marked decrease in the APX activity in the leaves of Ni-tolerant halophyte species M. crystallinum leaves. By contrast, an increase in this enzyme activity was observed in B. juncea leaves. The increase in APX activity was also observed in Triticum aestivum [70], Hordeum vulgare [71] and Oryza sativa leaves [35] subjected to Ni. In our study, the increase of SOD and APX activities in the shoots of $B$. juncea suggest that this metal induces the generation of their substrates, respectively, $\mathrm{O}_{2}{ }^{-}$et $\mathrm{H}_{2} \mathrm{O}_{2}$, while the same $\mathrm{Ni}$ doses did not induce the production of these oxidative molecules in the shoots of $M$. crystallinum.

In the roots of both species, Ni enhanced the GPX activity. This suggests that $\mathrm{Ni}$ induces the accumulation of $\mathrm{H}_{2} \mathrm{O}_{2}$ in the roots of tested species. Similar results have been reported in Ni-treated 
Piceaabies [72], Sileneparadoxa [73] and Pisum sativum [74] indicating a potential defensive role of GPX against Ni-induced oxidative stress.

Contrary to APX and GPX activities, CAT activity in the B.juncea and M.crystallinum plants did not exhibit a clear cut response to Ni exposure. This is consistent with other studies showing that CAT activity generally remained unchanged in Crotalaria juncea [75], Phaseolus vulgaris [76] and Hordeum vulgare [66] subjected to $\mathrm{Ni}$. Although, CAT has been considered among the most important antioxidant enzymes, it seems hence forth that its importance in the detoxification of $\mathrm{H}_{2} \mathrm{O}_{2}$ is reduced, excepting that derived from the peroxisomal metabolism in relation to photorespiration process [77,78]. Some authors believe that peroxidases assume the major role in detoxifying harmful reactive oxygen species in plants. CAT would be a "reel" to limit excessive production of ROS [79]. However, this assumption may be wrong because, although the results are frequently contradictory in the literature, the catalase activity is often negatively affected during heavy metal stress [55,70].

In addition to antioxidant enzymes, plants also use other mechanisms to scavenge reactive oxygen species in order to limit their possible destructive impact on cells. This system, commonly named the non-enzymatic antioxidative system, comprises molecules such as ascorbic acid, non-proteins thiols, $\alpha$-tocopherol, polyamines and proline that can detoxify ROS and maintain their levels at non-damaging levels [23]. Non protein thiols compounds may be found in most plant and they play a key role in the regulation of the redox equilibrium and the heavy metals detoxification $[31,80]$. In the present study, $\mathrm{Ni}^{2+}$ increased the NPT content in the roots (Table 2) and the shoots in both species. These increases were more elevated in the more Ni-tolerant species, M. crystallinum. This is consistent with previous studies showing the increase of NPT levels in the leaves of Oryza sativa and Hordeum vulgare $[35,66]$.

Glutathione is a well-known antioxidant playing a prominent role in the cell defense. It is a powerful reductant and hence a very efficient scavenger of ROS [81,82]. An active detoxification mechanism developed by plants, to avoid heavy metal poisoning involves intracellular sequestration of metal ions by means of glutathione and phytochelatines [83]. In this study, the GSH concentrations increased significantly in both roots and leaves of B. juncea. The same tendency was observed in M. crystallinum roots, whereas leaves GSH concentrations decreased (Table 2). This significant accumulation of GSH, especially in the roots, suggests its possible implication in $\mathrm{Ni}$ (II) chelation and sequestration in these organs. In addition, several earlier studies revealed that GSH acts as a first non-enzymatic line of defense against metal toxicity by directly complexing metals $[83,84]$. GSH is able to bind to free metal ions forming non-toxic complexes protecting cell structure and limiting the generation of oxidative stress damage $[23,85]$. For instance, in several Ni-hypeaccumulators species such as Thlaspi, it has been reported that GSH is strongly implicated in the $\mathrm{Ni}$ accumulation and tolerance [31].

In addition to low molecular -SH rich peptides, proline has long been recognized as an important protector against several abiotic stresses [86-88]. Proline synthesis under stress alleviates cytoplasmic acidosis and maintains the $\mathrm{NADP}^{+} / \mathrm{NADPH}$ ratio at functional and metabolic levels [88]. Furthermore, proline acts as osmoprotectant and membrane stabilizer [89]. Several earlier studies have also shown that proline can acts as an efficient ROS scavenger [90,91]. Our results showed that proline concentration was greatly increased in the roots and leaves of Ni-exposed plants, and the increase was more pronounced in leaves than roots in both B.juncea and M.crystallinum (Figure 1b). Our findings agree with other studies reporting proline increase in Ni-treated Nicotiana tabacum [92] and Triticum aestivum [19]. Proline accumulates in many plant species exposed to other heavy metals such as cadmium [93-95]. Despite several reports on proline accumulation in plants exposed to heavy metals, there is no clear consensus on the mechanism by which proline alleviates heavy metal toxicity. However, nickel, like numerous other heavy metals, can affect the plant water balance [18]. It is plausible that proline accumulated in Ni-stressed plants may be implicated in osmoregulation. On the other hand, it has been frequently reported that proline protect proteins structures [27,96], stabilizes cell membrane [86] and reduce the excessive production of ROS [19,23,91]. 


\section{Conclusions}

Taken together, the results of this study show that the halophyte, Mesembryanthemum crystallinum was more tolerant to nickel constraint than the glycophyte B. juncea. In fact, under the same Ni-dose, malondialdehyde content in the glycophyte species increased to a higher extent than in the halophyte. Accordingly, the activities of antioxidant enzymes (SOD, APX and GPX) in B. juncea increased faster than in M.crystallinum, suggesting a higher level of oxidative stress induced by $\mathrm{Ni}$ in B.juncea. The coordinated increase of the enzymes activities was effective in protecting the plant from the accumulation of ROS under Ni stress. However, the shoots of M. crystallinum, exhibited a surprising decrease in SOD activity in Ni-treated plants as compared to control ones, while Ni accumulated to higher concentration than in B. juncea. Furthermore, it may be suggested that the elevated level of NPT, glutathione and proline, (non-enzymatic antioxidative system), could be, at least partially, responsible for the development of resistance against nickel stress especially in M.crystallinum.

Author Contributions: T.A., A.S., M.P. and R.G. Conducted the experiments, TA participated to the redaction of the MS, T.G. and C.A. supervised the work in Tunisia, G.A.S. supervised the work in Italy for the determination of N.P.T., proline and G.S.H., T.G. and S.L. designed, wrote and corrected the MS. All authors have read and agreed to the published version of the manuscript.

Funding: This research received any external funding.

Acknowledgments: This work was conducted in the Laboratory of Extremophile Plants in the Biotechnology Center of Borj Cedria, Tunisia. It supported by the Tunisian Ministry of Higher Education and Scientific Research (LR10CBBC02). Seeds of B.juncea (Acc PI 173874) were kindly provided by the North Central Region Plant Introduction Station (NCRPIS), United States Department of Agriculture (USDA) from United States of America. We are also grateful to Gian Attilio Sacchi, Dipartimento di ProduzioneVegetale, Università degli Studi di Milano, Italy for his kind help by providing reagents and materials for biochemical analyzes.

Conflicts of Interest: The authors declare no conflict of interest.

\section{Abbreviations}

$\begin{array}{ll}\text { APX } & \text { Ascorbate peroxidase } \\ \text { CAT } & \text { Catalase } \\ \text { DTPA } & \text { diethylenetriamine pentaacetic acid } \\ \text { DTNB } & \text { dithiobis-nitrobenzoic acid } \\ \text { DTNB } & \text { dithionitrobenzoic acid } \\ \text { DTT } & \text { dithiothreitol } \\ \text { DW } & \text { Dry Weight } \\ \text { ETDA } & \text { Ethylenediaminetetraacetic acid } \\ \text { FW; GSH } & \text { glutathione, Fresh weight } \\ \text { GPX } & \text { Guaiacol peroxidase } \\ \mathrm{H}_{2} \mathrm{O}_{2} & \text { Hydrogen Peroxide } \\ \text { OH } & \text { hydroxyl radicals } \\ \text { MDA } & \text { Malondialdehyde } \\ \text { NBT } & \text { nitroblue tetrazolium } \\ \text { NPT } & \text { Non-protein thiols } \\ \text { GSSG } & \text { oxidized glutathione } \\ \text { PMSF } & \text { phenyl-methyl-sulphonyl-fluoride } \\ \text { PS } & \text { Photosystem } \\ \text { ROS } & \text { reactive Oxygen Species } \\ \text { RGR } & \text { Relative growth rate } \\ \text { RH } & \text { Relative humidity } \\ \text { RDW } & \text { root biomass } \\ \text { SDW } & \text { shoot biomass } \\ \text { SSA } & \text { sulfosalicylic acid } \\ & \end{array}$




$\begin{array}{ll}\mathrm{O}_{2}^{-} & \text {Superoxide anion } \\ \text { SOD } & \text { superoxide dismutase } \\ \text { TBA } & \text { Thiobarbituric acid } \\ \text { TDFHA } & \text { tridecafluoroheptanoic acid } \\ \text { WPDW } & \text { whole plant dry weight }\end{array}$

\section{References}

1. Khan, S.; Hesham, A.E.L.; Qiao, M.; Rehman, S.; He, J.Z. Effects of Cd and Pb on soil microbial community structure and activities. Environ. Sci. Pollut. Res. 2010, 17, 288-296. [CrossRef] [PubMed]

2. Xiong, T.; Austruy, A.; Pierart, A.; Shahid, M. Kinetic study of phytotoxicity induced by foliar lead uptake for vegetables exposed to fine particles and implications for sustainable urban agriculture. J. Environ. Sci. 2016, 46, 16-27. [CrossRef] [PubMed]

3. Pierart, A.; Shahid, M.; Séjalon-Delmas, N.; Dumat, C. Antimony bioavailability: Knowledge and research perspectives for sustainable agricultures. J. Hazard. Mater. 2015, 289, 219-234. [CrossRef]

4. Jarup, L. Hazards of heavy metal contamination. Br. Med. Bull. 2003, 68, 167-182. [CrossRef] [PubMed]

5. Tezotto, T.; Favarin, J.L.; Azevedo, R.A.; Alleoni, L.R.F.; Mazzafera, P. Coffee is highly tolerant to cadmium, nickel and zinc: Plant and soil nutritional status, metal distribution and bean yield. Field Crop. Res. 2012, 125, 25-34. [CrossRef]

6. Hussain, M.B.; Ali, S.; Azam, A.; Hina, S.; Farooq, A.M.; Ali, B.; Bharwana, A.S.; Gill, M.B. Morphological, physiological and biochemical responses of plants to nickel stress: A review. Afr. J. Agric. Res. 2013, 8, 1596-1602.

7. Yusuf, M.; Fariduddin, Q.; Hayat, S.; Ahmad, A. Nickel: An overview of uptake, essentiality and toxicity in plants. Bull. Environ. Contam. Toxicol. 2011, 86, 1-17. [CrossRef]

8. Gratão, P.L.; Pompeu, G.B.; Capaldi, F.R.; Vitorello, V.A.; Lea, P.J.; Azevedo, R.A. Antioxidant response of Nicotiana tabacum cv. Bright Yellow 2 cells to cadmium and nickel stress. Plant Cell Tissue Organ Cult. 2008, 94, 73-83. [CrossRef]

9. Polacco, J.C.; Mazzafera, P.; Tezotto, T. Opinion-nickel and urease in plants: Still many knowledge gaps. Plant Sci. 2013, 200, 79-90. [CrossRef]

10. Dourado, M.N.; Franco, M.R.; Peters, L.P.; Martins, P.F.; Souza, L.A.; Piotto, F.A.; Azevedo, R.A. Antioxidant enzymes activities of Burkholderia spp. strains—oxidative responses to Ni toxicity. Environ. Sci. Pollut. Res. 2015, 22, 19922-19932. [CrossRef]

11. Vogel-Mikus, K.; Drobne, D.; Regvar, M. Zn, Cd and Pb accumulation and arbuscular mycorrhizal colonization of pennycress Thlaspi praecox Wulf. (Brassicaceae) from the vicinity of a lead mine and smelter in Slovenia. Environ. Pollut. 2005, 133, 233-242. [CrossRef] [PubMed]

12. Nishida, S.; Kato, A.; Tsuzuki, C.; Yoshida, J.; Mizuno, T. Induction of nickel accumulation in response to zinc deficiency in Arabidopsis thaliana. Int. J. Mol. Sci. 2015, 16, 9420-9430. [CrossRef] [PubMed]

13. De la Torre, V.S.G.; Majorel-Loulergue, C.; Gonzalez, D.A.; Soubigou-Taconnat, L.; Rigaill, G.J.; Pillon, Y.; Barreau, L.; Thomine, S.; Fogliani, B.; Burtet-Sarramegna, V. Wide cross-species RNA-Seq comparison reveals a highly conserved role for Ferroportins in nickel hyperaccumulation in plants. bioRxiv 2018, 420-729. [CrossRef]

14. Mohseni, R.; Ghaderian, S.M.; Schat, H. Nickel uptake mechanisms in two Iranian nickel hyperaccumulators, Odontarrhenabracteata and Odontarrhenainflata. Plant Soil 2018, 434, 263-269. [CrossRef]

15. Takafumi, M.; Koji, U.; Kenji, H.; Shiro, N.; Naoharu, M.; Hitoshi, O. Cloning of three ZIP/Nramp transporter genes from a $\mathrm{Ni}$ hyperaccumulator plant Thlaspi japonicum and their $\mathrm{Ni}^{2+}$-transport abilities. Plant Physiol. Biochem. 2005, 43, 793-801.

16. Seregin, I.V.; Kozhevnikova, A.D. Roles of root and shoot tissues in transport and accu-mulation of cadmium, lead, nickel, and strontium. J. Plant Physiol. 2008, 55, 1-22.

17. Chen, C.; Huang, D.; Liu, J. Functions and toxicity of nickel in plants: Recent advances and future prospects. Clean Soil Air Water 2009, 7, 304-313. [CrossRef] 
18. Amari, T.; Ghnaya, T.; Debez, A.; Taamali, M.; Benyoussef, N.; Lucchini, G.; Sacchi, G.A.; Abdelly, C. Comparative Ni tolerance and accumulation potentials between Mesembryanthemumcrystallinum (halophyte) and Brassica juncea: Metal accumulation, nutrient status and photosynthetic activity. J. Plant Physiol. 2014, 171, 1634-1644. [CrossRef]

19. Gajewska, E.; Wielanek, M.; Bergier, K.; Skłodowska, M. Nickelinduced depression of nitrogen assimilation in wheat roots. Acta Physiol. Plant 2009, 31, 1291-1300. [CrossRef]

20. Hao, F.; Wang, X.; Chen, J. Involvement of plasma-membrane NADPH oxidase in nickel-induced oxidative stress in roots of wheat seedlings. Plant Sci. 2006, 170, 151-158. [CrossRef]

21. Beckman, K.B.; Ames, B.N. Oxidative Decay of DNA. J. Biol. Chem. 1997, 32, 19633-19636. [CrossRef] [PubMed]

22. Gajewska, E.; Sklodowska, M. Effect of nickel on ROS content and antioxidative enzymeactivities in wheat leaves. Biometals 2007, 20, 27-36. [CrossRef] [PubMed]

23. Gill, S.S.; Tuteja, N. Reactive oxygen species and antioxidant machinery in abiotic stress tolerance in crop plants. Plant Physiol. Biochem. 2010, 48, 909-930. [CrossRef] [PubMed]

24. Ghnaya, T.; Zaier, H.; Baioui, R.; Sghaier, S.; Lucchini, G.; Sacchi, G.A.; Lutts, S.; Abdelly, C. Implication of organic acids in the long-distance transport and the accumulation of lead in Sesuviumportulacastrum and Brassica juncea. Chemosphere 2013, 90, 1449-1454. [CrossRef]

25. Mnasri, M.; Ghabriche, R.; Fourati, E.; Zaier, H.; Sabally, K.; Suzelle, B.S.; Lutts, S.; Abdelly, C.; Ghnaya, T. Cd and Ni transport and accumulation in the halophyte Sesuviumportulacastrum: Implication of organic acids in these processes. Front. Plant Sci. 2015, 5, 165-169.

26. Amari, T.; Lutts, S.; Taamali, M.; Lucchini, G.; Sacchi, G.A.; Abdelly, C.; Ghnaya, T. Implication of citrate, malate and histidine in the accumulation and Transport of nickel in Mesembryanthemumcrystallinum and Brassica juncea. Ecotox. Environ. Saf. 2016, 126, 122-128. [CrossRef]

27. Hayat, S.; Hayat, Q.; Alyemeni, M.N.; Wani, A.S.; Pichtel, J.; Ahmad, A. Role of proline under changing environments. Plant Signal. Behav. 2012, 7, 1456-1466. [CrossRef]

28. Sharma, S.S.; Schat, H.; Vooijs, R. In vitro alleviation of heavy metal-induced enzyme inhibition by proline. Phytochemistry 1998, 49, 1531-1535. [CrossRef]

29. Rastgoo, L.; Alemzadeh, A. Biochemical responses of Gouan (Aeluropuslittoralis) to heavy metal stress. Aust. J. Crop. Sci. 2011, 5, 375-383.

30. Saiyood, S.; Vangnai, A.S.; Inthorn, D.; Thiravetyan, P. Treatment of total dissolve solids from plastic industrial effluent by halophyte plants. Water Air Soil Pollut. 2012, 223, 4865-4873. [CrossRef]

31. Freeman, J.L.; Persans, M.W.; Nieman, K.; Albrecht, C.; Peer, W.; Pickering, I.J.; Salt, D.E. Increased glutathione biosynthesis plays a role in nickel tolerance in Thlaspi nickel hyperaccumulators. Plant Cell 2004, 16, 2176-2191. [CrossRef] [PubMed]

32. Wójcik, M.; Tukiendorf, A. Glutathione in adaptation of Arabidopsis thaliana to cadmium stress. Biol. Plant 2011, 55, 125-132. [CrossRef]

33. Yin, H.; Chen, Q.; Yi, M. Effets of short-term heat stress on oxidative damage and responses of antioxidant system in Lilium longiflorum. J. Plant Growth Regul. 2008, 54, 45-54. [CrossRef]

34. Bulbovas, P.; Souza, S.R.; Esposito, J.B.N.; Moraes, R.M.; Alves, E.S.; Domingos, M.; Azevedo, R.A. Assessment of the ozone tolerance of two soybean cultivars (Glycine max cv. Sambaíba and Tracajá) cultivated in Amazonian areas. Environ. Sci. Pollut. Res. 2014, 21, 10514-10524. [CrossRef] [PubMed]

35. Maheshwari, R.; Dubey, R.S. Nickel-induced oxidative stress and the role of antioxidant defence in rice seedlings. Plant Growth Regul. 2009, 59, 37-49. [CrossRef]

36. Ghnaya, T.; Nouairi, I.; Slama, I.; Messedi, D.; Grignon, C.; Abdelly, C.; Ghorbel, M.H. Cadmium effects on growth and mineral nutrition of two halophytes: SesuviumportulacastrumGovindjee and Mesembryanthemumcrystallinum. J. Plant Physiol. 2005, 162, 1133-1140. [CrossRef]

37. Reboreda, R.; Caçador, I. Halophyte vegetation influences in salt marsh retention capacity for heavy metals. Environ. Pollut. 2007, 146, 147-154. [CrossRef]

38. Zaier, H.; Ghnaya, T.; Lakhdar, A.; Baioui, R.; Ghabriche, R.; Mnasri, M.; Sghaier, S.; Lutts, S.; Abdelly, C. Comparative study of $\mathrm{Pb}$-phytoextraction potential in Sesuviumportulacastrum and Brassica juncea: Tolerance and accumulation. J. Hazard. Mater. 2010, 183, 609-615. [CrossRef]

39. Mazharia, M.; Homaeed, M. Annual halophyte Chenopidiumbotrys can phytoextract cadmium from contaminated soils. J. Basic Appl. Sci. Res. 2012, 2, 1415-1422. 
40. Taamalli, M.; Ghabriche, R.; Amari, T.; Mnasri, M.; Zolla, L.; Lutts, S.; Abdely, C.; Ghnaya, T. Comparative study of Cd tolerance and accumulation potential between Cakilemaritima L. (halophyte) and Brassica juncea L. Ecol. Eng. 2014, 71, 623-627. [CrossRef]

41. Arnon, D.I.; Hoagland, D.R. Crop production in artificial solutions and in soils withspecial reference to factors affecting yields and absorption of inorganic nutrients. Soil Sci. 1940, 50, 463-484.

42. Aldrich, M.V.; Gardea-Torresdey, J.L.; Peralta-Videa, J.R.; Parsons, J.G. Uptake and reduction of Cr (VI) to Cr (III) by mesquite (Prospis spp.): Chromate-plant interaction in hydroponics and solid media studied using XAS. Environ. Sci. Technol. 2003, 37, 1859-1864. [CrossRef]

43. Hunt, R. Basic Growth Analysis: Plant Growth Analysis for Beginners; Springer Science \& Business Media: Berlin/Heidelberg, Germany, 2012.

44. Hodges, M.D.; DeLong, J.M.; Forney, C.F.; Prange, R.K. Improving the thiobarbituric acid-reactive-substances assay for estimating lipid peroxidation in plant tissues containing anthocyanin and other interfering compounds. Planta 1999, 207, 604-611. [CrossRef]

45. Bradford, M.M. A rapid and sensitive method for the quantization of micrograms quantities of protein utilizing the principle of protein-dye binding. Ann. Biochem. 1976, 72, 248-254. [CrossRef]

46. Scebba, F.; Sebastiani, L.; Vitagliano, C. Protective enzymes against activated oxygen species in wheat (Triticum aestivum L.) seedlings: Responses to cold acclimation. J. Plant Physiol. 1999, 155, 762-768. [CrossRef]

47. Luck, H. Methods of Enzymatic Aanalysis; Verlag Chemie Academic Press: New York, NY, USA, 1965; pp. 885-888.

48. Nakano, Y.; Asada, K. Hydrogen peroxide is scavenged by ascorbate-specific peroxidase in spinach chloroplast. Plant Cell Physiol. 1981, 22, 867-880.

49. Fielding, J.L.; Hall, J.L. Abiochemical and cytochemical study of peroxidase activity in root of Pisum sativum. J. Exp. Bot. 1978, 29, 979-986.

50. Rijstenbil, J.W.; Haritonidis, S.; Malea, P.; Seferlis, M.; Wijnholds, J.A. Thiol pools and glutathione redox ratios as possible indicators of copper toxicity in the green macroalgae Enteromorpha spp. from the Scheldt estuary (SW Netherlands, Belgium) and Thermaikos Gulf (Greece, N Aegean Sea). Hydrobiologia 1998, 385, 171-181. [CrossRef]

51. Sgherri, C.L.M.; Navari-Izzo, F. Sunflower seedlings subjected to increasing water deficit stress: Oxidative stress and defence mechanisms. Physiol. Plant 1995, 93, 25-30. [CrossRef]

52. Armstrong, M.; Jonscher, K.; Reisdorph, N.A. Analysis of 25 underivatized amino acids in human plasma using ion-pairing reversed-phase liquid chromatography/time-of-flight mass spectrometry. Rapid Commun. Mass Spectrom. 2007, 21, 2717-2726. [CrossRef]

53. Bai, C.; Reilly, C.C.; Wood, B.W. Nickel deficiency disrupts metabolism of ureides, aminoacids, and organic acids of young pecan foliage. Plant Physiol. 2006, 140, 433-443. [CrossRef] [PubMed]

54. Fourati, E.; Wali, M.; Vogel-Mikus, K.; Abdelly, C.; Ghnaya, T. Nickel tolerance, accumulation and subcellular distribution in the halophytes Sesuviumportulacastrum and Cakilemaritima. Plant Physiol. Biochem. 2016, 108, 295-303. [CrossRef] [PubMed]

55. Boominathan, R.; Doran, P.M. Ni induced oxidative stress in roots of the Ni hyperac-cumulator, Alyssum bertolonii. New Phytol. 2002, 156, 205-215. [CrossRef]

56. Ferraz, P.; Fidalgo, F.; Almeida, A.; Teixeira, J. Phytostabilization of nickel by the zinc and cadmium hyperaccumulator Solanum nigrum L. Are metallothioneins involved? Plant Physiol. Biochem. 2012, 57, 254-260. [CrossRef]

57. Shahid, M.; Ferrand, E.; Schreck, E.; Dumat, C. Behavior and impact of zirconium in the soil-plant system: Plant and phytotoxicity. Rev. Environ. Contam. Toxicol. 2013, 221, 107-127.

58. Demiral, T.; Türkan, I. Comparative lipid peroxidation, antioxidant defense systems and proline content in roots of two rice cultivars differing in salt tolerance. Environ. Exp. Bot. 2005, 53, 247-257. [CrossRef]

59. Gajewska, E.; Skłodowska, M. Differential biochemical responses of wheat shoots and roots to nickel stress: Antioxidative reactions and proline accumulation. Plant Growth Regul. 2008, 54, 179-188. [CrossRef]

60. Dubey, D.; Pandey, A. Effect of nickel (Ni) on chlorophyll, lipid peroxidation and antioxidant enzymes activities in black gram (Vigna mungo) leaves. Int. J. Sci. Nat. 2011, 2, 395-401.

61. Halliwell, B.; Gutteridge, J.M.C. Free Radicals in Biology and Medicine, 3rd ed.; Oxford Science Publications: Oxford, UK, 1999. 
62. Maksymiec, W. Signaling responses in plants to heavy metal stress. Acta. Physiol. Plant. 2007, 29, $177-187$. [CrossRef]

63. Romero-Puertas, M.C.; Corpas, F.J.; Rodriguez-Serrano, M.; Gomez, M.; del Río, L.A.; Sandalio, L.M. Differential expression and regulation of antioxidative enzymes by $\mathrm{Cd}$ in pea plants. J. Plant Physiol. 2007, 164, 1346-1357. [CrossRef]

64. Zhang, Q.F.; Li, Y.Y.; Pang, C.H.; Lu, C.M.; Wang, B.S. NaCl enhances thylakoid-bound activity in the leaves of C3 halophyte Suaeda salsa L. Plant Sci. 2005, 168, 423-430.

65. Gomes-Juniora, R.A.; Moldes, C.A.; Delite, F.S.; Gratão, P.L.; Mazzafer, P.; Leac, P.J.; Azevedoa, R.A. Nickel elicits a fast antioxidant response in Coffea arabica cells. Plant Physiol. Biochem. 2006, 44, 420-429. [CrossRef] [PubMed]

66. Kumar, H.; Sharma, D.; Kumar, V. Nickel-induced oxidative stress and role of antioxidant defence in Barley roots and leaves. Int. J. Environ. Biol. 2012, 2, 121-128.

67. Papadopoulos, A.; Prochaska, C.; Papadopoulos, F.; Gantidis, N.; Metaxa, E. Determination and evaluation of cadmium, copper, nickel, and zinc in agricultural soils of western Macedonia, Greece. Environ. Manag. 2007, 40, 719-726. [CrossRef] [PubMed]

68. Seregin, I.V.; Ivanov, V.B. Physiological Aspects of Cadmium and Leads Toxic Effects on the Higher Plants. Russ. J. Plant Physiol. 2001, 48, 606-630. [CrossRef]

69. Ros, R.; Morales, A.; Segura, J.; Picazo, I. In Vivo and In Vitro Effects of Nickel and Cadmium on the Plasmalemma ATPase from Rice (Oryza sativa L.) Shoots and Roots. Plant Sci. 1992, 83, 1-6. [CrossRef]

70. Gajewska, E.; Sklodowska, M.; Slaba, M.; Mazur, J. Effect of nickel on antioxidative enzyme activities, proline and chlorophyll content in wheat shoots. Biol. Plant 2006, 50, 653-659. [CrossRef]

71. Jocsak, I.; Vegvari, G.; Rabnecz, G.; Droppa, M. Investigation of nickel stress induction in terms of metal accumulation and antioxidative enzyme activity in barley seedlings. Acta Biol. Szeged. 2008, 52, 167-171.

72. Radotic, K.; Ducic, T.; Mutavdzic, D. Changes in peroxidase activity and isozymes in spruce needles after exposure to different concentrations of cadmium. Environ. Exp. Bot. 2000, 44, 105-113. [CrossRef]

73. Gonnelli, C.; Galardi, F.; Gabbrielli, R. Nickel and copper tolerance and toxicity in three Tuscan populations of Sileneparadoxa. Physiol. Plant 2001, 113, 507-514. [CrossRef]

74. Gajewska, E.; Sklodowska, M. Antioxidative responses and proline level in leaves and roots of pea plants subjected to nickel stress. Acta. Physiol. Plant. 2005, 27, 329-339. [CrossRef]

75. Cardoso, P.F.; Gratao, P.L.; Gomes-Junior, A.L.; Medici, L.O.; Azevedo, R.A. Response of Crotalaria juncea to nickel exposure. Braz. J. Plant Physiol. 2005, 17, 267-272. [CrossRef]

76. Bouazizi, H.; Jouili, H.; Geitmann, A.; ElFerjani, E. Cupric stress induces oxidative damage marked by accumulation of $\mathrm{H}_{2} \mathrm{O}_{2}$ and changes to chloroplast ultrastructure in primary leaves of beans (Phaseolus vulgaris L.). Acta Biol. Hung. 2010, 61, 191-203. [CrossRef] [PubMed]

77. Foyer, C.H.; Noctor, G. Redox homeostasis and antioxidant signalling: A metabolic interface between stress perception and physiological responses. Plant Cell 2005, 17, 1866-1875. [CrossRef]

78. Halliwell, B. Reactive Species and Antioxidants. Redox Biology Is a Fundamental Theme of Aerobic Life. Plant Physiol. 2006, 141, 312-322. [CrossRef]

79. Willekens, H.; Chamnongpol, S.; Davey, M.; Schraudner, M.; Langebartels, C.; Montagu, M.V.; Inzé, D.; Camp, W.V. Catalase is a sink for $\mathrm{H}_{2} \mathrm{O}_{2}$ and is indispensable for stress defence in C3 plants. EMBO J. 1997, 16, 4806-4816. [CrossRef] [PubMed]

80. Rabenstein, D.L.; Guevremont, R.; Evans, C.A. Glutathione and Its Metal-Complexes. In Metal Ions in Biological Systems; Singel, H., Ed.; Marcel Dekker: New York, NY, USA, 1985; pp. 104-141.

81. Cánovas, D.; Vooijs, R.; Schat, H.; De Lorenzo, V. The role of thiol species in the hypertolerance of Aspergillus sp. P37 to arsenic. J. Biol. Chem. 2004, 279, 51234-51240. [CrossRef]

82. Nocito, F.F.; Lancilli, C.; Crema, B.; Fourcroy, P.; Davidian, J.C.; Sacchi, G.A. Heavy metal stress and sulfate uptake in maize roots. Plant Physiol. 2006, 141, 1138-1148. [CrossRef]

83. Estrella-Gomez, N.; Mendoza-Cózatl, D.; Moreno-Sanchez, R.; Gonzalez-Mendoza, D.; Zapata-Perez, O.; Martinez-Hernandez, A.; Santamaria, J.M. The Pb-hyperaccumulator aquatic fern Salvinia minima Baker, responds to $\mathrm{Pb}^{2+}$ by increasing phytochelatins via changes in SmPCS expression and in phytochelatin synthase activity. Aquat. Toxicol. 2009, 91, 320-328. [CrossRef] 
84. Spuches, A.M.; Kruszyna, H.G.; Rich, A.M.; Wilcox, D.E. Thermodynamics of the As (III)-thiol interaction: Arsenite and monomethylarsenite complexes with glutathione, dihydrolipoic acid, and other thiol ligands. Inorg. Chem. 2005, 44, 2964-2972. [CrossRef]

85. Nadgórska-Socha, A.; Kafel, A.; Kandziora-Ciupa, M.; Gospodarek, J.; Zawisza-Raszka, A. Accumulation of heavy metals and antioxidant responses in Viciafaba plants grown on monometallic contaminated soil. Environ. Sci. Pollut. Res. 2013, 20, 1124-1134. [CrossRef] [PubMed]

86. Boaretto, L.F.; Carvalho, G.; Borgo, L.; Creste, S.; Landell, M.G.A.; Mazzafera, P.; Azevedo, R.A. Water stress reveals differential antioxidant responses of tolerant and non-tolerant sugarcane genotypes. Plant Physiol. Biochem. 2014, 74, 165-175. [CrossRef] [PubMed]

87. Sharma, S.S.; Dietz, K.J. The significance of amino acids and amino-derived molecules in plant responses and adaptation to heavy metal stress. J. Exp. Bot. 2006, 57, 711-726. [CrossRef] [PubMed]

88. Lei, Y.B.; Korpelainen, H.; Li, C.Y. Physiological and biochemical responses to high Mn concentrations in two contrasting Populuscathayana populations. Chemosphere 2007, 68, 686-694. [CrossRef]

89. Szabados, L.; Savouré, A. Proline: A multifunctional amino acid. Trends Plant Sci. 2009, 15, 89-97. [CrossRef]

90. Okuma, E.; Murakami, Y.; Shimoishi, Y.; Tada, M.; Murata, Y. Effects of exogenous application of proline and betaine on the growth of tobacco cultured cells under saline conditions. Soil Sci. Plant Nut. 2004, 50, 1301-1305. [CrossRef]

91. Kaul, S.; Sharma, S.; Mehta, I. Free radical scavenging potential of L-proline: Evidence from in vitro assays. Amino Acids 2008, 34, 315-320. [CrossRef]

92. Kolodyazhnaya, Y.S.; Titov, S.E.; Kochetov, A.V.; Trifonova, E.A.; Romanova, A.V.; Komarova, M.L.; Shumny, V.K. Tobacco transformants expressing antisense sequence of proline dehydrogenase gene possess tolerance to heavy metals. Russ. J. Genet. 2007, 43, 825-828. [CrossRef]

93. Tamas, L.; Dudikova, J.; Durcekova, K.; Haluskova, L.; Huttova, J.; Mistrik, I.; Olle, M. Alterations of the gene expression, lipid peroxidation, proline and thiol content along the barley root exposed to cadmium. J. Plant Physiol. 2008, 165, 1193-1203. [CrossRef]

94. Dinakar, N.; Nagajyothi, P.C.; Suresh, S.; Udaykiran, Y.; Damodharam, T. Phytotoxicity of cadmium on protein, proline and antioxidant enzyme activities in growing Arachis hypogaea L. seedlings. J. Environ. Sci. 2008, 20, 199-206. [CrossRef]

95. Shevyakova, N.I.; Netronina, I.A.; Aronova, E.E.; Kuznetsov, V.V. Compartmentation of cadmium and iron in Mesembryanthemumcrystallinum plants during the adaptation to cadmium stress. Russ. J. Plant Physiol. 2003, 50, 678-685. [CrossRef]

96. Ozturk, L.; Demir, Y. In vivo and in vitro protective role of proline. Plant Growth Regul. 2002, 38, $259-261$. [CrossRef]

(C) 2020 by the authors. Licensee MDPI, Basel, Switzerland. This article is an open access article distributed under the terms and conditions of the Creative Commons Attribution (CC BY) license (http://creativecommons.org/licenses/by/4.0/). 